\title{
Russians wrangle over legal status of academy property
}

Moscow. The Russian President, Boris Yeltsin, has written to Vladimir Shumeyko, the Speaker of the Federal Council (the upper chamber of the Russian parliament) complaining that the council has altered the text of a planned law on science and science policy by the "deliberate substitution of some pages" sent to the president for his approval.

Yeltsin is also said to have informed Russia's newly appointed procuratorgeneral, Valery Skuratov, that the alterations may have infringed criminal laws covering the limits of the authority that can be exercised by public officials.

In his letter to Shumeyko on 23 December, Yeltsin says that analysis of the text of the law approved by the Federal Council earlier in December revealed seven alterations from a text earlier adopted by the State Duma. Under the Russian constitution, the Senate has no power to change anything in the laws adopted by the lower chamber. The apparent differences between the two versions have led Yeltsin to demand that the original version - and not the amended version - be sent to him.

That has raised some eyebrows in Moscow, as it is not unusual for the Senate to edit the text of documents passed by the Duma before officially approving them. Some scientists are linking Yeltsin's letter with his recent decision to appoint Yury Osipov, the president of the Russian Academy of Sciences (RAS), to Russia's ruling body, the Presidium.

This act was seen as largely symbolic reflecting the president's desire to demonstrate his support for science - and the letter to Shumeyko is being viewed by some as similarly motivated. But the weakness in this explanation is that the amended version of the science law would put the academy in a stronger position than the original version by giving it ownership of its own facilities.

According to Vladimir Grachev, chairman of the Senate Committee on Science, Culture and Education, when the bill was received from the State Duma on 30 November, members of his committee found "some drawbacks of mainly stylistic origin" and asked Duma officers to make corrections on two pages.

The following week, the first deputy speaker of the Duma, Michail Mityukov, sent to the Senate an official letter asking for seven pages to be replaced by a new version "due to technical mistakes". These appear to be the changes referred to by Yeltsin in his letter.

The conflict appears to have arisen over an additional revised page, sent personally to the Senate by the speaker of the Duma,
Ivan Rybkin, and, according to the Senate's legal department, containing changes that would alter the main thrust of the new law.

The original text had specified that the RAS and branch academies were to be given the rights to "control their activities and federal property" and to "possess, utilize and command the federal property given to them in administrative control and economic management" [emphasis added].

The proposed revision, however, states that the academies should have the "ownership" of all their property, including not only the scientific equipment but also the buildings, dwellings, sanatoriums, kindergartens, hospitals and so on. Shumeyko, the speaker of the council, subsequently sent a 70-page letter to Skuratov, suggesting that the changes in the bill spotted by Yeltsin had been made by the lower, and not the upper, chamber of the Russian parliament.

Asked how this could have happened, Nikolai Vorontsov, chairman of the former Duma's science subcommittee, who had presented the science law to a plenary debate, claimed that Viktor Shevelukha, a member of the communist faction, had managed when acting as chairman of the full Committee on Culture, Education and Science, to get Rybkin's signature on the letter to the council asking for reference to "control" to be changed to "ownership".

Interestingly, the version of the bill distributed during a meeting on science legislation in the State Duma last year (see Nature 378, 4; 1995) included a footnote indicating that Shevelukha was proposing to add the words "or in ownership" in the relevant clause. When the State Duma later rejected this proposal, Shevelukha managed to insert it in the text of the law himself - omitting the word "or".

Meanwhile, despite widespread discussion of the need to support Russian science during last month's election campaign for the Duma, little mention of the topic has been made since the victory of the newly resurgent communist forces.

Vorontsov was one of few prepared to comment. "No doubt, the things will change to the worse", he says, arguing that the science most likely to receive support is that related to the needs of government agencies - and primarily military research — "but not fundamental science".

Since Vorontsov, a strong supporter of basic science, failed in his bid for re-election to the Duma, his forecast may well come true. But as the proposed science law has not yet been signed by Yeltsin in its present pro-communist version, there is still some hope that basic science will not be totally neglected.

Carl Levitin

\section{Cancer fund likely to boost basic research under new director}

London. Paul Nurse, currently director of laboratory research at the Imperial Cancer Research Fund (ICRF) in London, is to take over as director general of the charity on 1 September. He will succeed Sir Walter Bodmer, who has been director general since 1991 of a charity which employs over 1,000 people and spends in excess of $£ 50$ million a year on cancer research.

Bodmer is to become principal of Hertford College at the University of Oxford. Nurse, who is 46 , headed a laboratory at 崩 the ICRF between 1984 and 1987. He returned to the ICRF in 1993

IMAGE after six years as UNAVAILABLE Iveagh Professor FOR COPYRIGHT of Microbiology at REASONS the University of Oxford.

The news of his appointment has been welcomed by

Nurse: appointment ICRF researchers, who have faced six welcomed by staff.

months of uncertainty following Bodmer's announcement of his departure last July. "Paul is a very highly regarded scientist," says one ICRF biochemist. "His goal is the pursuit of excellence. It might make people feel a little insecure, but you don't get a first class institution for nothing."

Nurse, whose research interests focus on an understanding of the genes which prompt cells to multiply, says one clear change of emphasis from his predecessor will be his desire to protect and promote basic research. "My predecessor thought that we understood enough basic research [about cancer]," says Nurse. "My view is that our knowledge remains limited, and that basic research must continue."

Nurse says another priority will be "translational research", involving the effective transfer of a laboratory idea into the clinical arena, and getting clinicians talking more productively with scientists.

Nurse has a wide range of extra-laboratory interests. For example, he has been active in promoting the public understanding of science, arguing that more emphasis needs to be placed on communicating the process of science, rather than publicizing its "gizmo" applications.

He is also a committed member of the opposition Labour Party, and has little hesitation in voicing his opinion that science has not prospered under the present government. "We need a change of government to allow us to have a fresh look at how science can be supported in the United Kingdom," he says. Ehsan Masood 